\title{
Total Water Quality And Total Human Health Hazard Indices Approach For Health Risk Evaluation With Oral Intake Pathway of Groundwater of Nitrate And Fluoride From A Rural Region of South India
}

Sakram Gugulothu ( $\sim$ drsakramguguloth@gmail.com )

drsakramgugulorh@gmail.com

N. Subbarao

Andhra University

Rashmirekha Das

Utkal University

Laxman Duvva

JNTU: Jawaharlal Nehru Technological University Hyderabad

Ratnakar Dhakate

NGRI: National Geophysical Research Institute CSIR

\section{Research Article}

Keywords: Groundwater, Total water quality index, Total Human health hazard index, Human health risk zones, Rural region, India

Posted Date: August 13th, 2021

DOI: https://doi.org/10.21203/rs.3.rs-775914/v1

License: (c) (i) This work is licensed under a Creative Commons Attribution 4.0 International License.

Read Full License 


\title{
Total water quality and total human health hazard indices approach for health risk evaluation with oral intake pathway of groundwater of nitrate and fluoride from a rural region of South India
}

\author{
Sakram Gugulothu*1, N. Subbarao ${ }^{2}$, Rashmirekha Das ${ }^{3}$, Laxman Kumar Duvva ${ }^{4}$ and Ratnakar Dhakate ${ }^{1}$ \\ ${ }^{* 1}$ CSIR-National Geophysical Research Institute, Hyderabad-500007, Telangana, India \\ ${ }^{2}$ Department of Geology, Andhra University, Visakhapatnam - 530 003, Andhra Pradesh, India \\ ${ }^{3}$ Department of Geology, Utkal University, Bhubaneswar - 751 004, Odisha, India \\ ${ }^{4}$ Centre for Environment, Jawaharlal Nehru Technological University, Hyderabad - 500 085, Telangana, India \\ *1. Corresponding author’s Email: drsakramguguloth@gmail.com
}

\section{Abstract}

Evaluation of chemical quality of groundwater and associated health hazards is a prerequisite for taking remedial measures elsewhere. A rural region of South India was, thus, chosen for the present study to assess the total quality of groundwater and also to decipher the human health risk zones with respect to adults and children due to the groundwater pollution with nitrate $\left(\mathrm{NO}_{3}^{-}\right)$and fluoride $\left(\mathrm{F}^{-}\right)$ions. Groundwater samples collected from the study region were determined for various chemical parameters. According to the total water quality index, groundwater quality is suitable for drinking purposes. However, the $\mathrm{NO}_{3}^{-}$(0.4 to 585.20 $\mathrm{mg} / \mathrm{L})$ and $\mathrm{F}^{-}(0.22$ to $5.41 \mathrm{mg} / \mathrm{L})$ ions exceed the drinking water quality limits of $45 \mathrm{mg} / \mathrm{L}$ and $1.5 \mathrm{mg} / \mathrm{L}$ in $34 \%$ and $25 \%$ of the groundwater samples, respectively. Nitrate fertilizers appeared as the chief source of $\mathrm{NO}_{3}^{-}$, and the fluoride minerals as the main source of $\mathrm{F}^{-}$in the groundwater body, which are further supported by principal component analysis. Total human health hazard index (THHHI) was observed to be higher than its tolerable limit of 1.0 in $63 \%$ and $73 \%$ of the groundwater samples in respect of $\mathrm{NO}_{3}^{-}$and $\mathrm{F}^{-}$of adults and children, respectively. The intensity of human health risk zones of THHHI (>1.0) was 1.37 times higher in children (5.69) than in children (4.15), which cover an area of $71.75 \%$ and $66.73 \%$, respectively. Thus, the effective strategic measures were recommended for the 
39

protection of groundwater resources from pollution and also for improving the human health conditions.

Keywords: Groundwater, Total water quality index, Total Human health hazard index, Human health risk zones, Rural region, India

\section{Introduction}

Because of the rapid climatic changes, groundwater is an essential source globally, especially for both drinking and irrigation purposes (Reddy and Sakram 2014). More than $85 \%$ of the rural population depends upon the groundwater resources for their daily needs (Kulkarni et al. 2015). Though about 60 to $85 \%$ of groundwater is utilized for drinking and agriculture purposes, respectively, in India (Sishidia et al. 2016; Sakram and Narsimha 2018), most of it has been contaminated by naturally processes and artificially activities (Alaya et al. 2014; Subba Rao et al. 2017). Natural contamination is due to the influence of toxic components existing in the soil and rocks (example: fluoride minerals), while the artificial agents such as poor drainage conditions, spillage of septic tanks, irrigation-return-flows, immense usage of agrochemicals, etc cause inferior quality of groundwater and consequently health problems (Sakram et al. 2018; Subba Rao and Chaudhary 2019; Wu et al. 2019a).

Recently the researchers are mainly focused their work on the chemical quality of groundwater and associated health problems with respect to nitrate $\left(\mathrm{NO}_{3}^{-}\right)$and fluoride $\left(\mathrm{F}^{-}\right)$ ions, as they are the most common toxicities in the groundwater (Qasemi et al. 2018; Subba Rao et al. 2020a, b). Nitrate is the most common in the regions of agricultural activities (especially due to nitrogen fertilizers), irrigation-return-flows, flowing of untreated household wastes sewage and septic tank leakages onto the ground, nitrogen-rich soils, and animal wastes (Marghade et al. 2015; Li et al. 2017; Shukla and Saxena 2018; Zhang et al. 2018; He 
and Wu 2019; He et al. 2019; Karunanidhi et al. 2019; Subba Rao et al. 2021a, b, c). About 118 million people drink water with a $\mathrm{NO}_{3}^{-}$level ranging from 45 to $100 \mathrm{mg} / \mathrm{L}$ and more than 108 million people consume water with higher than $100 \mathrm{mg} / \mathrm{L}$ of $\mathrm{NO}_{3}^{-}$in India (Karunanidhi et al. 2020). Approximately 200 million people suffer from high $\mathrm{F}^{-}$content (> $\left.1.5 \mathrm{mg} / \mathrm{L}\right)$ in the groundwater globally, especially from the countries, including Africa, China, Iran, Nigeria, Pakistan, South America, and Sri Lanka (Wu et al. 2015; Craig et al. 2015; Chen et al. (2017). The fluoride minerals (fluorite, apatite, biotite and hornblende) occurring in the basement rock such as hornblende-biotite, gneiss, and granites are the chief source of $\mathrm{F}^{-}$contamination of groundwater and the agrochemicals like phosphate fertilizers lead to rise the concentration of $\mathrm{F}^{-}$as secondary source in the groundwater (Subba Rao 2017a; Karunanidhi et al. 2019; 2020).

It is a well-known fact that the consumption of contaminated groundwater by $\mathrm{NO}_{3}^{-}$ more than $45 \mathrm{mg} / \mathrm{L}$ would cause methemoglobinemia (blue baby syndrome), where red blood cells reduce their ability to carry oxygen, which leads to shortness of breath, heart attack, and even death, especially in children. Sometimes, it leads to cancer also (WHO 2012). Whereas the $\mathrm{F}^{-}$higher than $1.5 \mathrm{mg} / \mathrm{L}$ causes severe fluorosis (BIS 2012). Globally, it was observed that children are more vulnerable in comparison with adults in respect of $\mathrm{NO}_{3}^{-}$and $\mathrm{F}^{-}$ions (Zhai et al. 2017; Rezael et al. 2018; Karunanidhi et al. 2020). In India, the potential risk of groundwater is a consequence of contamination of $\mathrm{NO}_{3}^{-}$and $\mathrm{F}^{-}$ions, where children are at a greater health risk than adults, hiking the non-carcinogenic problems in children (Ding et al. 2020; Kaur et al. 2020; Subba Rao et al. 2021a).

The present study region is a part of Telangana State, India, which is a rural area (Fig. 1). It has intensive and long-term practice. So, the influences of unlimited usage of chemical 
composts (nitrate, phosphate, and potassium verities), irrigation-return-flows, and animal wastes are the most common phenomena on the groundwater system. Basic sanitary facilities like disposal of household wastes, flowing of leakage of septic tanks, etc are poor conditions in the study region, which are known as the most contamination sources of groundwater. However, there is no scientific study so far on the human health risk, especially due to the drinking of $\mathrm{NO}_{3}^{-}$and $\mathrm{F}^{-}$polluted groundwater. People are depending upon the groundwater resources for their drinking purpose due to the lack of surface water supply. Therefore, the main focus of the present study is on the assessment of health risks caused by $\mathrm{NO}_{3}^{-}$and $\mathrm{F}^{-}$contaminations in the groundwater. The study facilitates the decision-making authorities for the protection of the groundwater quality from the pollutants, and thereby for improving the health conditions of the local community.

\section{Figure 1 should be placed here}

\section{Study region}

The present rural region is located in the southwestern part of Telangana, India. It lies between north latitude $17^{\circ} 23^{\prime}-17^{\circ} 25^{\prime}$ and east longitudes $77^{\circ} 45^{\prime}-78^{\circ} 50^{\prime}$, falling in Survey of India toposheet number 56G/15 and 56G/16 and covering a geographical area of $632.45 \mathrm{sq}$ kms (Fig. 1). The region comes under semi-arid climate with the annual average temperature varying from $14^{\circ} \mathrm{C}$ to $41^{\circ} \mathrm{C}$ and the annual average rainfall (5 years) of $937 \mathrm{~mm}$. The surface runoff has resulted from the development of sub-dendritic drainage pattern in the study region.

The prominent rock exposures in the study region are basalts and granites (Fig. 1). Laterite patches also occur. The basalts are fine-grained and dark-colored volcanic rocks, which are composed of calcic plagioclase feldspars and clinopyroxene with olivine, quartz, 
hornblende, nepheline, orthopyroxene, etc. The granites are generally medium- to coarsegrained. They contain the quartz, plagioclase and potassium feldspars, biotite, apatite, hornblende, etc. Basically, they are hard rocks. However, the occurrence of vesicular structures, cracks, and joints become aquifers in the basalts, while the presence of weathered and fractured rocks are the water-bearing formations in the granites. The laterites are porous, but they are slightly permeable with a limited areal extent. Groundwater occurs under water table to semi-confined conditions. Depth to groundwater table varies from $18 \mathrm{~m}$ to $28 \mathrm{~m}$ below ground level. The quality of groundwater is generally appeared to be potable in the fieldwork.

\section{Materials and methods}

A hundred bore wells were observed from the study region during May 2015 (Fig. 1). The groundwater samples were collected from them in one-liter capacity polythene bottles, which were cleaned with 1:1 dilute hydrochloric acid and wash away with distilled water three times before collecting the water samples, following the standard procedure (APHA 2012).

The $\mathrm{pH}$ and electrical conductivity (EC) were measured in the field, using their meters (Table 1). TDS were calculated by multiplying EC with 0.64 factor. The other chemical parameters $\left(\mathrm{Ca}^{2+}, \mathrm{Mg}^{2+}, \mathrm{Na}^{+}, \mathrm{K}^{+}, \mathrm{HCO}_{3}^{-}, \mathrm{Cl}^{-}, \mathrm{SO}_{4}^{2-}, \mathrm{NO}_{3}^{-}\right.$and $\left.\mathrm{F}^{-}\right)$were estimated, using the conventional procedures such as titration $\left(\mathrm{Ca}^{2+}, \mathrm{HCO}_{3}^{-}\right.$, and $\left.\mathrm{Cl}^{-}\right)$, calculation $\left(\mathrm{Mg}^{2+}\right)$, flame photometer $\left(\mathrm{Na}^{+}\right.$and $\left.\mathrm{K}^{+}\right)$, UV spectrophotometer $\left(\mathrm{SO}_{4}^{2-}\right.$ and $\left.\mathrm{NO}_{3}^{-}\right)$, and ionselective electrode $\left(\mathrm{F}^{-}\right)$, and following the standard water quality methods (APHA 2012). For the computation of analytical error, the total cations $\left(\mathrm{Ca}^{2+}+\mathrm{Mg}^{2+}+\mathrm{Na}^{+}+\mathrm{K}^{+}\right)$and the total anions $\left(\mathrm{HCO}_{3}^{-}+\mathrm{Cl}^{-}+\mathrm{SO}_{4}^{2-}+\mathrm{NO}_{3}^{-}+\mathrm{F}^{-}\right)$were used, which was observed to be $\pm 5 \%$ (Subba Rao 2017a), reflecting the reliability of the chemical data. 


\section{Comprehensive tool for utilization of groundwater quality for drinking}

137

138

139

140

141

142

143

144

147

148

149

150

151

152

153

154

155

156

157

The total water quality index (TWQI) is a comprehensive technique to express the overall drinking water quality in a single term (Subba Rao et al. 2020; Wu et al. 2020a). The first step in this index is the calculation of relative weight $\left(W_{i}\right)$, after assigning the unit weight $\left(w_{i}\right)$, for each chemical parameter on the basis of its relative significance on the human health (Eq. 1). The second step is the computation of rating of water quality $\left(q_{i}\right)$, which is divided by the concentration of chemical parameter $\left(C_{i}\right)$ with national drinking water quality standard $\left(S_{i}\right)$ for each chemical parameter (Eq. 2). The third step is the assessment of $S I_{i}$ by multiplication of $q_{i}$ with $W_{i}$ to each chemical parameter (Eq. 3). The last step is the computation of TWQI by adding all $S I_{i}$ in each sample (Eq. 4).

$$
\begin{aligned}
& W_{i}=\frac{w_{i}}{\sum \substack{n=1 \\
n=1}_{i} w_{i}} \\
& q_{i}+\frac{C_{i}}{S_{i}} x 100 \\
& S I_{i}=q_{i} x W_{i} \\
& T W Q I=\sum_{i=1}^{n} S I_{i}
\end{aligned}
$$

When the TWQI is less than 50, it indicates an excellent quality of quality; when it is from 50 to 100 , it shows a good quality of water; when it is between 100 and 200 , it specifies a poor quality of water; when it is from 200 and 300, it represents a very poor quality of water; when it is more than 300 , it suggests an unsuitable quality of water for drinking purpose.

\section{Human Health risk assessment}

The $\mathrm{NO}_{3}^{-}$and $\mathrm{F}^{-}$ions were chosen for the human health risk assessment. The oral intake procedure was selected for the computation of total human health hazard index (THHHI) 
161

162

163

164

165

166

167

168

169

170

171

172

with respect to adults and children (Li et al. 2019a, b; Wu et al. 2020). The THHHI was calculated as shown in Eqs. 4 to 6 (USEPA 1991, 2006).

$$
\begin{aligned}
& \mathrm{MDD}=\mathrm{CGW} \times \mathrm{IR} \times \mathrm{ED} \times \mathrm{EF} / \mathrm{MBW} \times \mathrm{MET} \\
& \mathrm{HHHQ}=\mathrm{MDD} / \mathrm{RFD}
\end{aligned}
$$

$$
\text { THHHI }=\sum_{\mathrm{i}=1}^{\mathrm{n}} \mathrm{HQ}_{\mathrm{i}}
$$

where $\mathrm{MDD}$ is the mean dosage of daily of $\mathrm{NO}_{3}^{-}$and $\mathrm{F}^{-}(\mathrm{mg} / \mathrm{kg} / \mathrm{day}), \mathrm{CGW}$ is the concentration of $\mathrm{NO}_{3}^{-}$and $\mathrm{F}^{-}$in the groundwater $(\mathrm{mg} / \mathrm{L})$, IR represents the ingestion rate (3 L/day for adults and 1.5 L/day for children), ED is the exposure duration (66.4 years for adults and 12 years for children), EF is the exposure frequency (365 days for both adults and children), MBW is the mean body weight (65 $\mathrm{kg}$ for adults and $18.7 \mathrm{~kg}$ for children), MET is the mean exposure time (24,236 days for adults and 4,380 for children), HHHQ is the hazard quotient, RfD is the reference dose for chronic oral exposure $\left(1.60 \mathrm{mg} / \mathrm{kg} / \mathrm{d}\right.$ for $\mathrm{NO}_{3}^{-}$and $0.06 \mathrm{mg} / \mathrm{kg} / \mathrm{d}$ for $\mathrm{F}^{-}$(ICMR 2009; UNDESA 2013; USEPA 2014; Brindha et al. 2016), and THHHI is the total human health hazard index (non-carcinogenic hazard).

The tolerable limit of THHHI is 1.0 (USEPA 2014). If it is above than 1.0, the noncarcinogenic risk of the pollutant is greater than the tolerable level. If it is below 1.0, the noncarcinogenic risk is at acceptable limit.

\section{Results and discussion}

\section{Groundwater characteristics}

The $\mathrm{pH}$ in the groundwater ranged from 6.30 to 8.90 with a mean of 7.14 (Table 1), which indicates that it is slightly acidic to highly alkaline nature. Three groundwater samples are 
exceeding the safe limit of $\mathrm{pH}$ (6.5 to 8.5) in drinking water, which causes damage to the mucous membranes (BIS 2012). The TDS was from 56 to $1024 \mathrm{mg} / \mathrm{L}$ with a mean of 291 $\mathrm{mg} / \mathrm{L}$. About $15 \%$ of the groundwater samples are higher than its the recommended limit of $500 \mathrm{mg} / \mathrm{L}$ allowing for drinking purposes, causing gastrointestinal irritation (BIS 2012).

\section{Table 1 should be placed here}

\section{Cations}

The $\mathrm{Ca}^{2+}$ content was from 8.02 to $152.30 \mathrm{mg} / \mathrm{L}$ being a mean of $49.60 \mathrm{mg} / \mathrm{L}$ (Table 1 ). Fourteen percent of the groundwater sample showed a non-acceptable limit $(75 \mathrm{mg} / \mathrm{L})$ of $\mathrm{Ca}^{2+}$ (BIS 2012). Weathering and dissolution of plagioclase feldspars are the chief sources of $\mathrm{Ca}^{2+}$ in the groundwater (Subba Rao et al. 2017). The $\mathrm{Mg}^{2+}$ was between 2.43 and 92.42 $\mathrm{mg} / \mathrm{L}$ with a mean of $23.53 \mathrm{mg} / \mathrm{L}$, which is more than the tolerable limit of $50 \mathrm{mg} / \mathrm{L}$ in $6 \%$ of the groundwater samples. The $\mathrm{Mg}^{2+}$ is mainly attributed to the dissolution of ferromagnesian minerals (olivine, pyroxene, biotite, etc.) occurring in the host rocks, in addition to humaninduced activities (Subba Rao 2021). The $\mathrm{Na}^{+}$was from 3 to $416 \mathrm{mg} / \mathrm{L}$, with a mean of 54.13 mg/L. Only one groundwater sample shows $\mathrm{Na}^{+}$more than the threshold limit of $\mathrm{Na}^{+} 200$ $\mathrm{mg} / \mathrm{L}$ (BIS 2012). The plagioclase feldspars in the basement rocks are the prime source and the anthropogenic origin (household wastes, irrigation-return-flows, etc) is another source of $\mathrm{Na}^{+}$in the groundwater (Subba Rao 2021). The $\mathrm{K}^{+}$ranged from 1 to $118 \mathrm{mg} / \mathrm{L}$ and its mean is 6.20. This exceeds the desirable limit of $12 \mathrm{mg} / \mathrm{L}$ in $10 \%$ of the groundwater samples. The orthoclase feldspars are the prime source and the potassium composts are the secondary source of $\mathrm{K}^{+}$in the groundwater. 
Anions

The $\mathrm{HCO}_{3}^{-}$was from 146.40 to $2,538 \mathrm{mg} / \mathrm{L}$, with a mean of $1,014.31 \mathrm{mg} / \mathrm{L}$ (Table 1 ), which is caused by soil $\mathrm{CO}_{2}$. This is released from the decay of organic decomposition (Subba Rao et al. 2017). The $\mathrm{HCO}_{3}^{-}$is greater than its allowable limit of $300 \mathrm{mg} / \mathrm{L}$ for drinking purposes in $99 \%$ of the groundwater samples (BIS 2012). The concentration of $\mathrm{Cl}^{-}$was between 17.73 and $425.40 \mathrm{mg} / \mathrm{L}$ with a mean of $127.52 \mathrm{mg} / \mathrm{l}$. According to the drinking water quality standards, the $\mathrm{Cl}^{-}$is more than $250 \mathrm{mg} / \mathrm{L}$ in $10 \%$ of the groundwater samples, causing a salty taste and laxative effect. Non-lithological source (domestic waste waterss, irrigation-returnflows, etc) is the prime contributor of $\mathrm{Cl}^{-}$in the groundwater (Sarath Prasanth et al. 2012; Laxman et al. 2019). The value of $\mathrm{SO}_{4}^{2-}$ was from 30 to $166 \mathrm{mg} / \mathrm{L}$ and its mean is 97.90 $\mathrm{mg} / \mathrm{L}$. It is not more than its acceptable limit of $200 \mathrm{mg} / \mathrm{L}$ in all groundwater samples. Since no traces of sulphide minerals in the country rocks, utilization of gypsum for alternation of conditions is the only source of $\mathrm{SO}_{4}^{2-}$ in the groundwater body (Subba Rao et al. 2017). disease (BIS 2012). The $\mathrm{NO}_{3}^{-}$is a result of the influence of sewage wastes, septic tanks leakage, agricultural fertilizers and animal wastes on the aquifer system (Marghade et al., 2015; Zhang et al. 2018; He et al. 2019). In the present study region, the $\mathrm{F}^{-}$was from 0.22 to $5.41 \mathrm{mg} / \mathrm{L}$, with a mean of $1.13 \mathrm{mg} / \mathrm{L}$. It exceeds $1.5 \mathrm{mg} / \mathrm{L}$ in $25 \%$ of the groundwater samples, causing fluorosis. The occurrence of fluoride containing minerals like fluorite, biotite, hornblende, etc. in the host rocks and the usage of phosphate composts in the agricultural area are the main sources of $\mathrm{F}^{-}$in the groundwater body (Subba Rao et al. 2016, 2020a). 


\section{Total groundwater quality assessment for drinking purpose}

The total water quality index (TWQI) is a scale to measure the overall drinking water quality (Subba Rao et al. 2020a). The computed values of TWQI were from 30 to 91 with a mean of 52.72 (Table 2). According to the classification of TWQI, 51\% and $49 \%$ of the groundwater samples come under the excellent (TWQI: < 50) and good (TWQI: 50 to 100) water quality types for drinking purposes, respectively. It suggests that the quality of groundwater is fit very well for drinking purposes without any water treatment.

\section{Table 2 should be placed here}

However, when we observed the individual chemical parameters from Table 1, it is apparent that all chemical parameters such as $\mathrm{Ca}^{2+}, \mathrm{Mg}^{2+}, \mathrm{Na}^{+}, \mathrm{K}^{+}, \mathrm{HCO}_{3}^{-}, \mathrm{Cl}^{-}$and $\mathrm{SO}_{4}^{2-}$, (excepting $\mathrm{NO}_{3}^{-}$and $\mathrm{F}^{-}$ions) are more than highest desirable limits of $75,30,200,12,300$, 250 , and $200 \mathrm{mg} / \mathrm{L}$, respectively, in less than $15 \%$ of the groundwater samples. But in the case of $\mathrm{NO}_{3}^{-}$and $\mathrm{F}^{-}$ions, they are above the safe limits of $45 \mathrm{mg} / \mathrm{L}$ and $1.5 \mathrm{mg} / \mathrm{L}$ in $34 \%$ and $25 \%$ of the total groundwater samples, respectively (BIS 2012; WHO 2012). Further, these two ions are the most common toxicities than the rest of the chemical parameters in the drinking water because of their potential production of non-carcinogenic risk (USEPA 2014).

Since agriculture is one of the main practices of the present study region, a considerable portion of applied agrochemicals (nitrogen fertilizers) is expected to penetrate the soils/rocks, in addition to the influences of household waste waters, septic tank leakages, and animal excretions, and reaching the aquifer body through the recharge water. This is likely to increase the $\mathrm{NO}_{3}^{-}$levels in the groundwater. However, $\mathrm{NO}_{3}^{-}$levels less than $45 \mathrm{mg} / \mathrm{L}$ were observed from $54.69 \%$ of the total study region (Fig. 2a). They were mainly confined to 
the northern part and however were also found as very limited isolated pockets in the southern part, where the agricultural activities are comparatively less. Next higher $\mathrm{NO}_{3}^{-}$ levels (45 to $100 \mathrm{mg} / \mathrm{L}$ and $>100 \mathrm{mg} / \mathrm{L}$ ) were mainly observed in the southern part in $46.31 \%$ of the total study region, where the agricultural activities are more. Therefore, the influences of utilization of nitrogen fertilizers, irrigation-return-flows, and animal wastes are expected on the aquifer system. This hypothesis is further substantially supported by the increasing of $\mathrm{NO}_{3}^{-}\left(9.38\right.$ to $186.12 \mathrm{mg} / \mathrm{L}$ ) along with TDS (212.33 to $480 \mathrm{mg} / \mathrm{L}$ ), $\mathrm{Na}^{+}$(39.82 to 89.18 $\mathrm{mg} / \mathrm{L})$ and $\mathrm{Cl}^{-}(112.70$ to $178.54 \mathrm{mg} / \mathrm{L})$, and also by the higher loading of $\mathrm{NO}_{3}^{-}(0.813)$ along with TDS (0.851), $\mathrm{Na}^{+}(0.660)$ and $\mathrm{Cl}^{-}(0.768$; Tables 3 and 4), which are the most common indicators of human-induced pollution (Subba Rao et al. 2017).

\section{Figure 2 should be placed here}

\section{Tables 3 and 4 should be placed here}

The higher alkalinity $\left(\mathrm{pH}\right.$ and $\mathrm{HCO}_{3}^{-}$) with $\mathrm{Na}^{+}$activates the leaching of fluoride minerals occurring in the basement rocks and thus increases the higher $\mathrm{F}^{-}$content in the groundwater system (Subba Rao et al. 2016, 2020a). Apart from this, usage of phosphate fertilizers may also lead to an increase of concentration of $\mathrm{F}^{-}$in the groundwater (Subba Rao et al. 2021a). Spatial distribution of concentration of $\mathrm{F}^{-}$ion in the groundwater of the present study region showed that the $\mathrm{F}^{-}$level less than $0.6 \mathrm{mg} / \mathrm{L}$ was observed mainly from the northern part and also as very limited isolated patches in the southern part, which covers an area of $20.36 \%$ of the total study region (Fig. 2b). A safe limit of $\mathrm{F}^{-}(0.6$ to $1.5 \mathrm{mg} / \mathrm{L})$ was found in the study region $(58.47 \%)$. The next higher $\mathrm{F}^{-}$content $(>1.5 \mathrm{mg} / \mathrm{L}$ was found as isolated pockets $(21.17 \%)$ from the entire study region irrespective of the agricultural activities. As demonstrated in Tables 3 and 4 , the concentration of $\mathrm{F}^{-}(0.40$ to $2.42 \mathrm{mg} / \mathrm{L})$ 
shows an increase with an increase of $\mathrm{pH}$ (7.02 to 7.30$), \mathrm{Na}^{+}(22.24$ to $83.83 \mathrm{mg} / \mathrm{L})$, and $\mathrm{HCO}_{3}^{-}(863.98$ to $1099.78 \mathrm{mg} / \mathrm{L})$, and the higher loading of $\mathrm{F}^{-}(0.732)$ also shows the higher loadings of $\mathrm{pH}(0.519), \mathrm{Na}^{+}(0.552)$ and $\mathrm{HCO}_{3}^{-}(0.555)$, which obviously indicates that the spatial distribution of $\mathrm{F}^{-}$content could be mainly caused by the influence of weathering and dissolution of fluoride-bearing minerals occurring in the host rocks rather than that of phosphate fertilizers on the groundwater system.

According to WHO (2011), excessive $\mathrm{NO}_{3}^{-}$levels in the drinking water affects the health of children and adults, whereas the high $\mathrm{F}^{-}$levels provide a health risk to people of all ages. For computation of THHHI, the mean body weight is $65 \mathrm{~kg}$ for adults and $18.7 \mathrm{~kg}$ for children, and the mean exposure time is 24,236 days for adults and 4,380 days for children are taken into consideration (ICMR 2009; USEPA 2014). From this point of view, we have decided to evaluate the health risks between adults and children with respect to $\mathrm{NO}_{3}^{-}$and $\mathrm{F}^{-}$pollutants in the present study.

\section{Human health risk with respect to nitrate and fluoride}

The values of the human health hazard quotient of nitrate $\left(\mathrm{HHHQ}_{\mathrm{NO}_{3}^{-}}\right)$varied from 0.01 to 19.08 for adults and from 0.01 to 29.34 for children, with a mean of 1.83 and 2.82 , respectively (Table 2). Out of 100 groundwater samples, $39 \%$ and $47 \%$ of the samples showed $\mathrm{HHHQ}_{\mathrm{NO}_{3}^{-}}^{-}$more than 1.0 with respect to adults (4.26) and children (5.68), respectively, causing a health risk. The human health hazard quotient of fluoride $\left(\mathrm{HHHQ}_{\mathrm{F}}{ }^{-}\right)$ was between 0.19 and 4.70 for adults and between 0.29 and 7.23 for children, with a mean of 0.99 and 1.52 , in which $36 \%$ and $58 \%$ of the groundwater samples had $\mathrm{HHHQ}_{\mathrm{F}}{ }^{-}$more than 1.0 with respect to adults (1.78) and children (2.14), respectively, causing a health hazard. It 
is also significantly observed from Table 2 that children are more threatening to health risks due to the $\mathrm{NO}_{3}^{-}$rather than the $\mathrm{F}^{-}$compared to adults. According to WHO (2011) and Subba Rao et al. $(2017,2019 b)$, the groundwater could have been more contaminated with $\mathrm{NO}_{3}^{-}$due to the influences of anthropogenic sources (household wastes, septic tanks leakage, irrigationreturn-flows, nitrogen fertilizers, animal wastes, etc) compared to the source of $\mathrm{F}^{-}$.

\section{Total human health implications}

321

In order to evaluate the total implications of $\mathrm{NO}_{3}^{-}$and $\mathrm{F}^{-}$ions on the human health, the total human health hazard index (THHHI) was computed, following the Eqs. 4 to 6 . The values of THHHI varied from 0.27 to 20.4 for adults and 0.26 to 19.6 for children (Table 2). According to the USEPA (2014), the recommended safe limit of THHHI for the non-cancer-causing hazard is 1.0 in the drinking water. In the present study region, the THHHI was more than 1.0 in $63 \%$ and $73 \%$ of the total groundwater samples with respect to adults and children, respectively. It is also further observed that the mean THHHI is 2.82 for adults and 4.34 for children. It obviously suggests that the danger is a threat to children than to adults. This lesser exposure time of children compared to adults (USEPA 2014). of THHHI for adults and children was demonstrated in Fig. 3. The zones with less than 1.0 and more than 1.0 of THHHI were covered by $33.27 \%$ and $66.73 \%$ for adults and $28.25 \%$ and $71.75 \%$ for children of the total study region, respectively. The first zone was in safe limit (average THHHI: 0.54 for adults and 0.66 for children) with respect to non-cancer health risk, while another one was in the unsafe limit (average THHHI: 4.15 for adults and 
5.69 for children) of non-cancer health problem (Table 3). Thus, the intensity of human health risk zone appears to be 1.37 times higher in children than in adults. These two zones have obviously divided the region into the northern safe health zone and the southern unsafe health zone, respectively, depending upon the intensity of the agricultural activities.

\section{Figure 3 should be placed here}

The human health risk zone of the southern part appears to be caused by the influence of the unlimited application of nitrogen fertilizers compared to that of fluoride minerals and phosphate composts. This fact is established by observing the spatial distribution of $\mathrm{NO}_{3}^{-}$and $\mathrm{F}^{-}$contents (Fig. 2), where the $\mathrm{F}^{-}$ion shows mostly the safe health zone compared to the $\mathrm{NO}_{3}^{-}$associated non-cancer risk. Li et al. (2019a) from China and Subba Rao et al. (2021a) from India stated that the main $\mathrm{NO}_{3}^{-}$content is a result of the influence of agricultural fertilizers of the human-induced sources in the groundwater. Further, because of the intensive agricultural practices in the southern part, it is also important to consider the influences of return-irrigation-flows and animal wastes as a source of higher $\mathrm{NO}_{3}^{-}$in the groundwater (Marghade et al., 2015). Therefore, the study helps for deciphering the specific sites of the human health risk zones (THHHI $>1.0$ ) in the case of children (71.75\%) and adults (66.73\%; Fig. 3) for taking remedial measures for sustainable health conditions.

\section{Remedial measures}

The intensity of susceptible zones for the purpose of protecting and managing groundwater resources from pollution is essential for making health society for long-term growth. Since the groundwater is the only resource for the locals, the present study suggests some useful 
and easily applicable remedial measures such as (a) supply of safe drinking water to maintain

367 the normal health, (b) arrangements of denitrification and defluoridation tools to reduce the $\mathrm{NO}_{3}^{-}$and $\mathrm{F}^{-}$contents, (c) implementation of rainwater harvesting techniques to dilute the groundwater salinity, including the concentrations of $\mathrm{NO}_{3}^{-}$and $\mathrm{F}^{-}$ions, (d) providing the hygienic-sanitary facilities for clean surrounding residential locations, (e) utilization of limited chemical fertilizers, according to the soil conditions, to arrest the contamination activities, and (f) education of the local population on environmental protection and management.

\section{Conclusions}

The following conclusions were summarized, after observing the chemical quality of groundwater and associated health problems in respect of $\mathrm{NO}_{3}^{-}$and $\mathrm{F}^{-}$ions at age groups of adults and children, using total water quality index (TWQI) and total human health hazard index (THHHI), from a rural region of Telangana State of India:

The TWQI suggested that the chemical quality of groundwater is suitable for drinking purposes. However, the $\mathrm{NO}_{3}^{-}$varying from 0.4 to $585.20 \mathrm{mg} / \mathrm{L}$ and $\mathrm{F}^{-}$from 0.22 to 5.41 $\mathrm{mg} / \mathrm{L}$ exceed the consumption water quality limits of $45 \mathrm{mg} / \mathrm{L}$ and $1.5 \mathrm{mg} / \mathrm{L}$ in $34 \%$ and $25 \%$ of the total groundwater samples, respectively. Nitrate fertilizers are the main source of $\mathrm{NO}_{3}^{-}$content and the fluoride minerals as the prime source of $\mathrm{F}^{-}$content in the groundwater. They are further supported by principal component analysis.

$>$ According to the THHHI, $63 \%$ and $73 \%$ of the total groundwater samples associated adults and children were more than its safe limit of 1.0 with respect to $\mathrm{NO}_{3}^{-}$and $\mathrm{F}^{-}$, respectively. The intensity of human health risk zones of THHHI was 1.37 times more in 
children (5.69) than in children (4.15), covering an area of $71.75 \%$ and $66.73 \%$, respectively.

394

The present study was recommended effective management measures not only for the protection of groundwater resources from pollution activities but also for improving the health conditions of the locals.

\section{Funding information:}

At present, no funding is available for the publication of this research work.

\section{Reference:}

Alaya, M. B., Saidi, S., Zemni, T., \& Zargouni, F. (2014). Suitability assessment of deep groundwater for drinking and irrigation use in the Djefara aquifers (Northern Gabes, south-eastern Tunisia). Environmental Earth Sciences, 71, 3387-3421. https://doi.org/10.1007/s12665-013-2729-9.

APHA (1995) Standard Methods for the Examination of Water and Wastewater. 19th ed. American Public Association, Washington, DC, USA

BIS (2012) Indian standard drinking water specification, Second Revision Bureau of Indian Standards, Drinking Water Sectional Committee, FAD 25. New Delhi, India. ISO: 10500:2012

Brindha K, Jagadeshan G, Kalpana L, Elango L (2016) Fluoride in weathered rock aquifers of southern India: managed Aquifer recharge for mitigation. Environ Sci Pollut Res 23:8302-8316

Chen, J., Wu, H., Qian, H., \& Gao, Y. (2017). Assessing nitrate and fluoride contaminants in drinking water and their health risk of rural residents living in a semi-arid region of 

016-0231-9.

421

422

423

424

425

426

427

Craig, L. Stillings, L. L., Decker, D. L., \& Thomas, J. M. (2015). Comparing activated alumina with indigenous laterite and bauxite as potential sorbents for removing fluoride from drinking water in Ghana. Applied Geochemistry, 56, 50-66. https://doi.org/10.1016/j. apgeochem.2015.02.004.

Ding, L., Yang, Q., Yang, Y., Ma, H., \& Martin, J. D. (2020). Potential risk assessment of groundwater to address the agricultural and domestic challenges in Ordos Basin. Environmental Geochemistry and Health. https://doi.org/10.1007/s10653-019-00512-2.

He, X., Wu, J., He, S., 2019. Hydrochemical characteristics and quality evaluation of groundwater in terms of health risks in Luohe aquifer in Wuqi County of the Chinese Loess Plateau, Northwest China. Hum. Ecol. Risk Assess. 25 (1-2), 32-51. https://doi. org/10.1080/10807039.2018.1531693.

He, S., Wu, J., 2019. Hydrogeochemical characteristics, groundwater quality and health risks from hexavalent chromium and nitrate in groundwater of Huanhe Formation in Wuqi County, Northwest China. Exp. Health 11, 125-137. https://doi.org/10.1007/ s12403018-0289-7.

Hem JD (1991) Study and interpretation of the chemical characteris tics of natural water; U.S. Geological Survey Water Supply Paper 2254, p 264. Scientifc Publishers, Jodhpur, India

ICMR (Indian Council of Medical Research) (2009) Nutrient requirements and recommended dietary allowances for Indians. A report of the expert group of the ICMR, Hyderabad, India, p 334

Karunanidhi,D., Aravinthasamy, P., Priyadarsi, D. R., Praveenkumar, R. M., Prasanth, K., Selvapraveen, S (2020). Evaluation of non-carcinogenic risks due to fluoride and nitrate 
contaminations in a groundwater of anurban part (Coimbatore region) of south India. Environmental Monitoring and Assessment, 192, 102. https://doi.org/10.1007/s10661019-8059-y.

Karunanidhi, D., Aravinthasamy, P., Subramani, T., Jianhua, W., \& Srinivasamoorthy, K. (2019). Potential health risk assessment for fluoride and nitrate contamination in hard rock aquifers of Shanmuganadhi River basin, South India. Human Ecological Risk Assessment: An International Journal. https://doi.org/10.1080/10807039.2019.1568859.

Kaur, L., Rishi, M. S., \& Siddiqui, A. U. (2020). Deterministic and probabilistic health risk assessment techniques to evaluate non-carcinogenic human health risk (NHHR) due to fluoride and nitrate in groundwater of Panipat, Haryana, India. Environmental Pollution. https://doi.org/10.1016/j. envpol.2019.113711.

Kulkarni, H., Shah, M., Vijay Shankar, P.S. 2015. Shaping the contours of groundwater governance in India. Journal of Hydrology: Regional Studies. 4: 172-192. https://doi.org/10.1016/j.ejrh.2014.11.004

Laxman Kumar D, Satyanarayana E, Ratnakar Dhakate, Praveen Raj Saxena (2019) Hydrochemical characteristics with respect to fluoride contamination in groundwater of Maheshwaram mandal, RR district, Telangana state, India. Groundwater for Sustainable Development 8:474-483

Li, P., Feng, W., Xue, C., Rui, Tian, Wang, S., 2017. Spatiotemporal variability of contami1nants in Lake water and their risks to human health: a case study of the Shahu lake tourist area, Northwest China. Expo Health 9, 213-225.

Li, P., \& Wu, J. (2019a). Drinking water quality and public health. Exposure and Health, 11(2), 73-79. https://doi.org/10.1007/s12403-019-00299-8. 
Li P, Tian R, Liu R (2019b) Solute geochemistry and multivariate analysis of water quality in the Guohua phosphorite mine, Guizhou Province, China. Exposure and Health, 11(2):81-94

Reddy M, Sakram G (2014) Climate Change and water resources: Implications and mitigation, International Journal of Recent Scientific Research. (ISSN 0976-3031, Volume 05, No. 01: PP.201-204

Marghade D, Malpe DB, Subbarao N (2015) Identification of controlling processes of groundwater quality in a developing urban area using principal component analysis. Environmental Earth Sciences, 74: 5919-5933

Qasemi, M., Afsharnia, M., Farhang, M., Bakhshizadeh, A., Allahdadi, M., \& Zarei, A. (2018). Health risk assessment of nitrate exposure in groundwater of rural areas of Gonabad and Bajestan, Iran. Environmental Earth Sciences, 77, 551. https://doi.org/10.1007/s12665-018-7732-8.

Rezaei, H., Ali, J., Bahram, K., \& Mohammad, S. (2018). Health-risk assessment related to the fluoride, nitrate, and nitrite in the drinking water in the Sanandaj, Kurdistan County, Iran. Human Ecological Risk Assessment: An International Journal, 25(5), 1-9. https://doi.org/10.1080/ 10807039.2018.1463510.

Sakram G, Narsimha Adimalla (2018) Hydrogeochemical characterization and assessment of water suitability for drinking and irrigation in crystalline rocks of Mothkur region, Telangana State, South India. Applied Water Science, 8:143

Sakram G, Sreedhar Kuntamalla, Machender G, Ratnakar Dhakate, Narsimha A (2018) Multivariate statistical approach for the assessment of fluoride and nitrate concentration in groundwater from Zaheerabad area, Telangana State, India. Sustainable Water Resources Management, https://DOI.org/10.1007/s40899-018-0258-0 
Sarath Prasanth SV, Magesh NS, Jitheshlal KV, Chandrasekar N (2012) Evaluation of groundwater quality and its suitability for drinking and agricultural use in the coastal stretch of Alappuzha district, Kerala, India. Appl Water Sci 2(3):165-175

Sishodia, R. P., Shukla, S., Graham, W. D., Wani, S. P., \& Garg,K. K. (2016). Bi-decadal groundwater level trends in a semi-arid south indian region: Declines, causes and management. Journal of Hydrology: Regional Studies, 8, 43-58. https://doi.org/10.1016/j.ejrh.2016.09.005.

Subba Rao, N. (2017a). Controlling factors of fluoride in groundwater in a part of South India. Arabian Journal of Geosciences, 10, 524. https://doi.org/10.1007/s12517-017$3291-7$.

Subba Rao, N. (2017b). Hydrogeology: Problems with solutions. New Delhi: Prentice Hall of India

Subba Rao, N. (2021) Spatial distribution of quality of groundwater and probabilistic noncarcinogenic risk from a rural dry climatic region of South India. Environmental Geochemistry and Health. 43:971-993. https://doi.org/10.1007/s10653-020-00621-3(

Subba Rao, N., Chaudhary, M. (2019). Hydrogeochemical processes regulating the spatial distribution of groundwater contamination, using pollution index of groundwater (PIG) and hierarchical cluster analysis (HCA): A case study. Groundwater for Sustainable Development. https://doi. org/10.1016/j.gsd.2019.100238.

Subba Rao, N, Deepali, M, Dinakar, A, Chandana, I, Sunitha, B, Ravindra, B. and Balaji, T. (2017). Geochemical characteristics and controlling factors of chemical composition of groundwater in a part of Guntur district, Andhra Pradesh, India. Environmental Earth Science, 76:747. https://doi.org/10.1007/s12665-017-7093-8

Subba Rao, N., Dinakar, Karuna Kumari, B. (2021a). Appraisal of vulnerable zones of noncancer-causing health risks associated with exposure of nitrate and fluoride in 
groundwater from a rural part of India. Environmental Research, 111674, https://doi.org/10.1016/j.envres.2021.111674

518

Subba Rao, N., Dinakar, A., Karuna Kumari, B., Karunanidhi, D., Kamalesh, T. (2021b). Seasonal and spatial variation of groundwater quality vulnerable zones of Yellareddygudem watershed, Nalgonda district, Telangana State, India. Archives Environmental Contamination and Toxicology, 80: 1-30, https://doi.org/10.1007/s00244-020-00783-2

Subba Rao, N., Dinakar, A., Sravanthi, M., Karuna Kumari, B. (2021c). Geochemical characteristics and quality of groundwater evaluation for drinking, irrigation and industrial purposes from a part of hard rock aquifer of South India. Environmental Science and Pollution Research. 28: 31941-31961, https://doi.org/10.1007/s11356021-12404-Z

Subba Rao, N., Dinakar, A., Surya Rao, P., Rao, P.N., Madhnure, P., Prasad, K.M., Sudarshan, G., 2016. Geochemical processes controlling fluoride-bearing groundwater in the granitic aquifer of a semi-arid region. Journal of Geological Society of India 88:350-356. https://doi.org/10.1007/s12594-016-0497-3

Subba Rao, N., Ravindra, B., \& Wu, J. (2020a). Geochemical and health risk evaluation of fluoride rich groundwater in Sattenapalle Region, Guntur district, Andhra Pradesh, India. Human Ecological Risk Assessment: An International Journal. https://doi.org/10.1080/10807039.2020. 1741338.

Subba Rao, N., Sunitha, B., Adimalla, N., \& Chaudhary, M. (2020b). Quality criteria for groundwater use from a rural part of Wanaparthy District, Telangana State, India, through ionic spatial distribution (ISD), entropy water quality index (EWQI) and principal component analysis (PCA). Environmental Geochemistry and Health, 42, 579-599. https://doi.org/10.1007/s10653-019-00393-5. 
541 Subba Rao, N., Sunitha, B., Sun, L., Deepthi Spandana, B., \& Chaudhary, M. (2019b). Mechanisms controlling groundwater chemistry and assessment of potential health risk, A case study from South India. Geochemistry, https://doi.org/10.1016/j.chemer. 2019.125568

Shukla S., Saxena A. (2018) Global Status of Nitrate Contamination in Groundwater: Its Occurrence, Health Impacts, and Mitigation Measures. In: Hussain C. (eds) Handbook of Environmental Materials Management. Springer, Cham. https://doi.org/10.1007/9783-319-58538-3_20-1

UNDESA (United Nations Department of Economic and Social Affairs) (2013) World Population Prospects. Population Division Database. Detailed indicators 2012 Revision. USEPA (1991) Risk assessment guidance for superfund. Vol 1: Human Health Evaluation Manual (Part B, Development of Risk-Based Preliminary Remediation Goals). EPA19585.7-01B. Office of Emergency and Remedial Response, United States Environmental Protection Agency, Wash1ington, DC.

USEPA (2006) USEPA Region III risk-based concentration Table: Technical background information. United States Environmental Protection Agency, Washington, DC

USEPA (2014) Human health evaluation manual, supple1mental guidance: Update of Standard Default Exposure Factors-OSWER Directive 9200.1-120. PP.6.

WHO, 2012. Guidelines for Drinking Water Quality. fourth ed. World Health Organizationation.

Wu, J., Li, P., \& Qian, H. (2015). Hadrochemical characterization of drinking groundwater with special reference to fluoride in an arid area of China and the control of aquifer leakage on its concentrations. Environmental Earth Sciences, 73(12), 8575-8588. https://doi.org/10.1007/s12665-015-4018-2 
Wu, J., Li, P., Wang, D., Ren, X., \& Wei, M. (2019). Statistical and multivariate statistical techniques to trace the sources and affecting factors of groundwater pollution in a rapidly

growing city on the Chinese Loess Plateau. Human Ecological Risk Assessment: An International Journal. https:// doi.org/10.1080/10807039.2019.1594156.

Wu, J., Zhang, Y., \& Zhou, H. (2020). Groundwater chemistry and groundwater quality index incorporating health risk weighting in Dingbian County, Ordos basin of northwest China. Geochemistry. https://doi.org/10.1016/j.chemer. 2020.125607.

Zhai, Y., Zhao, X., Teng, Y., Li, X., Zhang, J., Wu, J., Zuo, R., 2017. Groundwater nitrate pollution and human health risk assessment by using HHRA model in an agricultural area, NE China. Ecotoxicol. Environ. Saf. 137, 130-142. https://doi.org/10.1016/j. ecoenv.2016.11.010

Zhang Y, Wu J, Xu B (2018) Human health risk assessment of groundwater nitrogen pollution in Jinghui canal irrigation area of the loess region, northwest China. Environ Earth Sci 77, Article 273. DOI: 10.1007/s12665-018-7456-9

\section{Captions to Figures}

Fig. 1. Map showing the location of the rural region of the present study Fig. 2. Map showing the spatial distribution of (a) $\mathrm{NO}_{3}^{-}$and (b) $\mathrm{F}^{-}$ions

Fig. 3. Map showing the spatial distribution of total human health hazard index (THHHI) with respect to (a) adults and (b) children 
Table 1: Statistical summary of chemical composition of groundwater

\begin{tabular}{|c|c|c|c|c|c|c|c|c|}
\hline \multirow{2}{*}{$\begin{array}{l}\text { Chemical } \\
\text { parameters }\end{array}$} & \multirow{2}{*}{ Minimum } & \multirow{2}{*}{ Maximum } & \multirow{2}{*}{ Mean } & \multirow{2}{*}{$\begin{array}{c}\text { BIS } \\
(2012)\end{array}$} & \multicolumn{2}{|c|}{ Samples exceeding the drinking water quality limits } & \multirow{2}{*}{ Analytical methods } & \multirow{2}{*}{ Reference } \\
\hline & & & & & Percent & Sample numbers & & \\
\hline $\mathrm{pH}$ & 6.30 & 8.90 & 7.14 & $6.5-8.5$ & 3 & 17,26, and 79 & $\mathrm{pH} / \mathrm{EC} / \mathrm{TDS}$ meter & APHA (2012) \\
\hline TDS (mg/L) & 56 & 1024 & 291.0 & 500 & 15 & $\begin{array}{c}1 \text { to } 5,14,16,19,20,22,29,41,43,54 \text {, } \\
\text { and } 55 .\end{array}$ & EC $\times 0.645$ & Hem 1991 \\
\hline $\mathrm{Ca}^{2+}(\mathrm{mg} / \mathrm{L})$ & 8.02 & 152.30 & 49.60 & 75 & 14 & $\begin{array}{c}41,43,49,51,53 \text { to } 55,63,64,66,68,70 \\
90, \text { and } 98 .\end{array}$ & EDTA Titrimetric & APHA (2012) \\
\hline $\mathrm{Mg}^{2+}(\mathrm{mg} / \mathrm{L})$ & 2.43 & 92.42 & 23.53 & 50 & 6 & $3,55,91,94,97$, and 99 & Calculation $\left(\mathrm{TH}-\mathrm{Ca}^{2+}\right)$ & APHA (2012) \\
\hline $\mathrm{Na}^{+}(\mathrm{mg} / \mathrm{L})$ & 3 & 416 & 54.13 & 200 & 1 & 43 & Flame photometric & APHA (2012) \\
\hline $\mathrm{K}^{+}(\mathrm{mg} / \mathrm{L})$ & 1 & 118 & 6.20 & 12 & 10 & $1,16,20,29,35,45,53,88,89$, and 96 & Flame photometric & APHA (2012) \\
\hline $\mathrm{HCO}_{3}^{-}(\mathrm{mg} / \mathrm{L})$ & 146.40 & 2538 & 1014.31 & 300 & 99 & 1 to 29, and 31 to 100 & Titrimetric & APHA (2012) \\
\hline $\mathrm{Cl}^{-}(\mathrm{mg} / \mathrm{L})$ & 17.73 & 425.40 & 127.52 & 250 & 10 & $16,41,43,54,55,63,66,70,91$, and 99 & $\mathrm{AgNO}_{3}$ titrimetric & APHA (2012) \\
\hline $\mathrm{SO}_{4}^{2-}(\mathrm{mg} / \mathrm{L})$ & 30 & 166 & 97.90 & 200 & - & 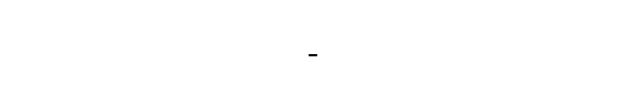 & $\begin{array}{l}\text { UV Visible } \\
\text { spectrophotometer }\end{array}$ & APHA (2012) \\
\hline $\mathrm{NO}_{3}^{-}(\mathrm{mg} / \mathrm{L})$ & 0.04 & 585.20 & 56.27 & 45 & 34 & $\begin{array}{l}2 \text { to } 6,8,9 \text { to } 11,13,14,16,18,20,22,24, \\
25,30,33,41 \text { to } 44,46,47,49,51 \text { to } 55, \\
63,66 \text {, and } 67 .\end{array}$ & $\begin{array}{l}\text { UV Visible } \\
\text { spectrophotometer }\end{array}$ & APHA (2012) \\
\hline $\mathrm{F}^{-}(\mathrm{mg} / \mathrm{L})$ & 0.22 & 5.41 & 1.13 & 1.5 & 25 & $\begin{array}{l}3,7,19 \text { to } 25,28,34,36,38,39,40,42 \\
43,50,56,59,61,64, \text { and } 72 \text { to } 74 .\end{array}$ & Ion selective electrode & APHA (2012) \\
\hline
\end{tabular}


Table 2: Computed values of total water quality index (TWQI), human health hazard quotient (HHHQ) and total human health hazard index (THHHI) (Bold letters denote exceeding the recommended limit)

\begin{tabular}{|c|c|c|c|c|c|c|c|c|}
\hline \multirow{2}{*}{$\begin{array}{c}\text { Sample } \\
\text { No. }\end{array}$} & \multicolumn{2}{|r|}{ TWQI } & \multicolumn{2}{|c|}{$\mathrm{HHHQ}_{\mathrm{NO}^{3}}{ }^{3}$} & \multicolumn{2}{|c|}{$\mathrm{HHHHQ}_{\mathrm{F}}{ }^{-}$} & \multicolumn{2}{|c|}{$\mathrm{THHHI}_{\mathrm{NO}^{3}}{ }^{-}{ }_{\mathrm{F}}^{-}$} \\
\hline & Value & Classification & Adult & Children & Adult & Children & Adult & Children \\
\hline 1 & 62 & Good & 0.81 & 1.25 & 0.87 & 1.34 & 1.68 & 2.59 \\
\hline 2 & 53 & Good & 8.39 & 12.90 & 0.78 & 1.20 & 9.18 & 14.11 \\
\hline 3 & 89 & Good & 4.92 & 7.57 & 1.39 & 2.14 & 6.31 & 9.71 \\
\hline 4 & 66 & Good & 4.61 & 7.08 & 0.26 & 0.40 & 4.87 & 7.48 \\
\hline 5 & 60 & Good & 5.85 & 9.00 & 0.35 & 0.53 & 6.20 & 9.53 \\
\hline 6 & 41 & Excellent & 5.35 & 8.23 & 0.61 & 0.94 & 5.96 & 9.16 \\
\hline 7 & 58 & Good & 0.06 & 0.10 & 3.04 & 4.68 & 3.11 & 4.78 \\
\hline 8 & 39 & Excellent & 2.35 & 3.62 & 0.43 & 0.67 & 2.79 & 4.29 \\
\hline 9 & 33 & Excellent & 3.87 & 5.96 & 0.26 & 0.40 & 4.13 & 6.36 \\
\hline 10 & 37 & Excellent & 3.39 & 5.21 & 0.26 & 0.40 & 3.65 & 5.61 \\
\hline 11 & 47 & Excellent & 1.65 & 2.54 & 0.43 & 0.67 & 2.08 & 3.21 \\
\hline 12 & 34 & Excellent & 1.33 & 2.05 & 0.35 & 0.53 & 1.68 & 2.59 \\
\hline 13 & 48 & Excellent & 4.68 & 7.19 & 0.35 & 0.53 & 5.03 & 7.73 \\
\hline 14 & 50 & Excellent & 2.70 & 4.15 & 0.70 & 1.07 & 3.39 & 5.22 \\
\hline 15 & 42 & Excellent & 0.66 & 1.02 & 0.78 & 1.20 & 1.45 & 2.22 \\
\hline 16 & 67 & Good & 19.08 & 29.34 & 1.04 & 1.60 & 20.13 & 30.94 \\
\hline 17 & 62 & Good & 0.12 & 0.18 & 1.04 & 1.60 & 1.16 & 1.78 \\
\hline 18 & 63 & Good & 7.40 & 11.38 & 1.13 & 1.74 & 8.53 & 13.12 \\
\hline 19 & 73 & Good & 0.20 & 0.30 & 1.39 & 2.14 & 1.59 & 2.44 \\
\hline 20 & 70 & Good & 2.88 & 4.43 & 2.00 & 3.07 & 4.88 & 7.51 \\
\hline 21 & 63 & Good & 0.55 & 0.85 & 1.30 & 2.01 & 1.86 & 2.86 \\
\hline 22 & 69 & Good & 3.44 & 5.29 & 2.35 & 3.61 & 5.79 & 8.90 \\
\hline 23 & 80 & Good & 0.95 & 1.46 & 3.57 & 5.48 & 4.51 & 6.94 \\
\hline 24 & 62 & Good & 1.94 & 2.98 & 2.26 & 3.48 & 4.20 & 6.45 \\
\hline 25 & 55 & Good & 2.91 & 4.48 & 2.26 & 3.48 & 5.17 & 7.95 \\
\hline 26 & 50 & Excellent & 0.14 & 0.21 & 0.70 & 1.07 & 0.83 & 1.28 \\
\hline 27 & 40 & Excellent & 0.04 & 0.06 & 0.78 & 1.20 & 0.82 & 1.26 \\
\hline 28 & 63 & Good & 0.07 & 0.11 & 1.65 & 2.54 & 1.73 & 2.65 \\
\hline 29 & 55 & Good & 0.12 & 0.18 & 0.78 & 1.20 & 0.90 & 1.39 \\
\hline 30 & 33 & Excellent & 3.33 & 5.12 & 0.58 & 0.90 & 3.91 & 6.01 \\
\hline 31 & 47 & Excellent & 0.89 & 1.37 & 0.72 & 1.10 & 1.61 & 2.47 \\
\hline 32 & 55 & Good & 0.18 & 0.27 & 1.26 & 1.94 & 1.44 & 2.21 \\
\hline 33 & 58 & Good & 4.16 & 6.40 & 1.07 & 1.64 & 5.23 & 8.04 \\
\hline 34 & 53 & Good & 1.08 & 1.66 & 1.48 & 2.27 & 2.56 & 3.93 \\
\hline 35 & 42 & Excellent & 0.15 & 0.23 & 0.83 & 1.27 & 0.98 & 1.50 \\
\hline 36 & 50 & Excellent & 0.86 & 1.32 & 1.43 & 2.21 & 2.29 & 3.53 \\
\hline 37 & 42 & Excellent & 0.32 & 0.49 & 0.28 & 0.43 & 0.59 & 0.91 \\
\hline 38 & 58 & Good & 1.14 & 1.76 & 1.37 & 2.11 & 2.52 & 3.87 \\
\hline 39 & 59 & Good & 0.76 & 1.18 & 1.63 & 2.51 & 2.40 & 3.69 \\
\hline 40 & 70 & Good & 0.24 & 0.37 & 1.63 & 2.50 & 1.87 & 2.87 \\
\hline 41 & 74 & Good & 6.76 & 10.39 & 0.97 & 1.48 & 7.72 & 11.87 \\
\hline
\end{tabular}




\begin{tabular}{|c|c|c|c|c|c|c|c|c|}
\hline 42 & 73 & Good & 1.81 & 2.78 & 1.90 & 2.91 & 3.70 & 5.69 \\
\hline 43 & 91 & Good & 6.18 & 9.51 & 1.89 & 2.90 & 8.07 & 12.41 \\
\hline 44 & 54 & Good & 4.25 & 6.53 & 0.66 & 1.02 & 4.91 & 7.55 \\
\hline 45 & 60 & Good & 0.28 & 0.43 & 0.71 & 1.10 & 0.99 & 1.53 \\
\hline 46 & 66 & Good & 1.88 & 2.89 & 0.79 & 1.22 & 2.67 & 4.11 \\
\hline 47 & 60 & Good & 2.96 & 4.54 & 0.81 & 1.24 & 3.76 & 5.79 \\
\hline 48 & 60 & Good & 0.85 & 1.31 & 0.95 & 1.46 & 1.80 & 2.76 \\
\hline 49 & 72 & Good & 3.20 & 4.92 & 1.27 & 1.95 & 4.47 & 6.87 \\
\hline 50 & 70 & Good & 0.36 & 0.55 & 1.41 & 2.17 & 1.76 & 2.71 \\
\hline 51 & 54 & Good & 2.27 & 3.49 & 1.03 & 1.59 & 3.30 & 5.08 \\
\hline 52 & 51 & Good & 3.23 & 4.96 & 0.75 & 1.15 & 3.98 & 6.11 \\
\hline 53 & 67 & Good & 4.86 & 7.48 & 0.57 & 0.88 & 5.44 & 8.36 \\
\hline 54 & 78 & Good & 7.36 & 11.32 & 0.50 & 0.76 & 7.86 & 12.08 \\
\hline 55 & 85 & Good & 11.79 & 18.13 & 0.93 & 1.43 & 12.72 & 19.56 \\
\hline 56 & 67 & Good & 1.07 & 1.65 & 1.99 & 3.06 & 3.06 & 4.71 \\
\hline 57 & 44 & Excellent & 0.98 & 1.50 & 0.80 & 1.23 & 1.78 & 2.73 \\
\hline 58 & 42 & Excellent & 0.62 & 0.95 & 1.05 & 1.62 & 1.67 & 2.57 \\
\hline 59 & 61 & Good & 1.30 & 1.99 & 2.73 & 4.20 & 4.03 & 6.19 \\
\hline 60 & 44 & Excellent & 0.42 & 0.65 & 0.57 & 0.88 & 1.00 & 1.54 \\
\hline 61 & 61 & Good & 0.27 & 0.42 & 2.41 & 3.70 & 2.68 & 4.12 \\
\hline 62 & 67 & Good & 0.13 & 0.20 & 1.23 & 1.90 & 1.37 & 2.10 \\
\hline 63 & 70 & Good & 3.57 & 5.49 & 1.13 & 1.74 & 4.70 & 7.23 \\
\hline 64 & 63 & Good & 0.36 & 0.55 & 1.55 & 2.38 & 1.91 & 2.93 \\
\hline 65 & 57 & Good & 1.46 & 2.25 & 1.10 & 1.68 & 2.56 & 3.93 \\
\hline 66 & 63 & Good & 6.34 & 9.75 & 0.85 & 1.31 & 7.19 & 11.06 \\
\hline 67 & 52 & Good & 3.92 & 6.02 & 0.89 & 1.36 & 4.80 & 7.39 \\
\hline 68 & 36 & Excellent & 0.15 & 0.23 & 0.51 & 0.79 & 0.66 & 1.02 \\
\hline 69 & 45 & Excellent & 0.06 & 0.10 & 0.58 & 0.90 & 0.65 & 1.00 \\
\hline 70 & 43 & Excellent & 0.19 & 0.30 & 0.33 & 0.51 & 0.52 & 0.81 \\
\hline 71 & 46 & Excellent & 0.01 & 0.01 & 0.81 & 1.24 & 0.82 & 1.26 \\
\hline 72 & 56 & Good & 0.02 & 0.03 & 1.33 & 2.05 & 1.35 & 2.07 \\
\hline 73 & 72 & Good & 0.01 & 0.01 & 3.13 & 4.81 & 3.14 & 4.82 \\
\hline 74 & 77 & Good & 0.01 & 0.01 & 4.70 & 7.23 & 4.71 & 7.24 \\
\hline 75 & 36 & Excellent & 0.01 & 0.02 & 0.57 & 0.88 & 0.58 & 0.90 \\
\hline 76 & 32 & Excellent & 0.05 & 0.07 & 0.34 & 0.52 & 0.38 & 0.59 \\
\hline 77 & 40 & Excellent & 0.02 & 0.04 & 0.35 & 0.53 & 0.37 & 0.57 \\
\hline 78 & 42 & Excellent & 0.02 & 0.04 & 0.28 & 0.43 & 0.30 & 0.47 \\
\hline 79 & 41 & Excellent & 0.01 & 0.01 & 0.19 & 0.29 & 0.20 & 0.30 \\
\hline 80 & 38 & Excellent & 0.01 & 0.01 & 0.33 & 0.51 & 0.34 & 0.52 \\
\hline 81 & 47 & Excellent & 0.05 & 0.07 & 0.50 & 0.78 & 0.55 & 0.85 \\
\hline 82 & 37 & Excellent & 0.05 & 0.08 & 0.46 & 0.71 & 0.51 & 0.79 \\
\hline 83 & 45 & Excellent & 0.05 & 0.07 & 0.75 & 1.15 & 0.79 & 1.22 \\
\hline 84 & 30 & Excellent & 0.05 & 0.08 & 0.22 & 0.33 & 0.27 & 0.41 \\
\hline 85 & 32 & Excellent & 0.02 & 0.02 & 0.33 & 0.51 & 0.35 & 0.53 \\
\hline 86 & 42 & Excellent & 0.01 & 0.01 & 0.39 & 0.60 & 0.40 & 0.61 \\
\hline 87 & 38 & Excellent & 0.04 & 0.06 & 0.38 & 0.59 & 0.42 & 0.65 \\
\hline 88 & 36 & Excellent & 0.02 & 0.03 & 0.49 & 0.75 & 0.51 & 0.78 \\
\hline 89 & 38 & Excellent & 0.00 & 0.00 & 0.59 & 0.91 & 0.59 & 0.91 \\
\hline 90 & 33 & Excellent & 0.02 & 0.03 & 0.22 & 0.33 & 0.24 & 0.36 \\
\hline
\end{tabular}




$\begin{array}{ccccccccc}91 & 47 & \text { Excellent } & 0.05 & 0.08 & 0.29 & 0.44 & 0.34 & 0.52 \\ 92 & 34 & \text { Excellent } & 0.04 & 0.06 & 0.30 & 0.47 & 0.34 & 0.52 \\ 93 & 32 & \text { Excellent } & 0.01 & 0.02 & 0.33 & 0.51 & 0.34 & 0.53 \\ 94 & 38 & \text { Excellent } & 0.03 & 0.05 & 0.45 & 0.70 & 0.48 & 0.74 \\ 95 & 39 & \text { Excellent } & 0.01 & 0.01 & 0.70 & \mathbf{1 . 0 7} & 0.71 & \mathbf{1 . 0 8} \\ 96 & 38 & \text { Excellent } & 0.05 & 0.08 & 0.58 & 0.90 & 0.63 & 0.97 \\ 97 & 32 & \text { Excellent } & 0.09 & 0.14 & 0.34 & 0.52 & 0.43 & 0.66 \\ 98 & 43 & \text { Excellent } & 0.02 & 0.03 & 0.33 & 0.51 & 0.35 & 0.54 \\ 99 & 43 & \text { Excellent } & 0.14 & 0.21 & 0.32 & 0.49 & 0.46 & 0.71 \\ 100 & 40 & \text { Excellent } & 0.12 & 0.19 & 0.38 & 0.59 & 0.50 & 0.78 \\ & & & & & & & & \\ \text { Mean } & 52.72 & & 1.83 & 2.82 & 0.99 & 1.52 & 2.82 & 4.34 \\ <1.0 & - & - & 0.21 & 0.17 & 0.53 & 0.6 & 0.54 & 0.66 \\ >1.0 & - & - & 4.26 & 5.68 & 1.78 & 2.14 & 4.15 & 5.69 \\ & & & & & & & & \end{array}$


Table 3. Mean values of $\mathrm{pH}, \mathrm{TDS}, \mathrm{Na}^{+}, \mathrm{HCO}_{3}^{-}$, and $\mathrm{Cl}^{-}$based on the classification of $\mathrm{NO}_{3}^{-}$ and $\mathrm{F}^{-}$

\begin{tabular}{|c|c|c|c|c|c|}
\hline \multicolumn{2}{|c|}{$\mathrm{NO}_{3}^{-}(\mathrm{mg} / \mathrm{L})$} & \multirow{2}{*}{$\begin{array}{c}\text { TDS } \\
(\mathrm{mg} / \mathrm{L})\end{array}$} & \multirow{2}{*}{$\begin{array}{c}\mathrm{Na}^{+} \\
(\mathrm{mg} / \mathrm{L})\end{array}$} & \multirow{2}{*}{$\begin{array}{c}\mathrm{Cl}^{-} \\
(\mathrm{mg} / \mathrm{L})\end{array}$} & \multirow{2}{*}{$\begin{array}{c}\text { Percent of } \\
\text { samples }\end{array}$} \\
\hline Range & Mean & & & & \\
\hline$<45$ & 9.38 & 212.13 & 39.82 & 112.70 & 66 \\
\hline 45 to 100 & 74.56 & 378.67 & 68.58 & 115.51 & 12 \\
\hline$>100$ & 186.12 & 480.00 & 89.18 & 178.54 & 22 \\
\hline \multicolumn{2}{|c|}{$\mathrm{F}^{-}(\mathrm{mg} / \mathrm{L}$} & $\mathrm{pH}$ & $\mathrm{Na}^{+}$ & $\mathrm{HCO}_{3}^{-}$ & Percent of \\
\hline Range & Mean & & & & \\
\hline$<0.6$ & 0.40 & 7.02 & 22.24 & 863.98 & 33 \\
\hline 0.6 to 1.5 & 0.98 & 7.11 & 62.02 & 1030.62 & 43 \\
\hline$>1.5$ & 2.42 & 7.30 & 83.83 & 1099.78 & 24 \\
\hline
\end{tabular}


Table 4. Principal component analysis

\begin{tabular}{lrrrr}
\hline \multirow{2}{*}{$\begin{array}{l}\text { Chemical } \\
\text { parameters }\end{array}$} & \multicolumn{4}{c}{ Principal Component Analysis } \\
\cline { 2 - 5 } $\mathrm{pH}$ & 0.302 & $\mathbf{0 . 5 1 9}$ & 0.316 & \multicolumn{1}{c}{0.201} \\
$\mathrm{TDS}$ & $\mathbf{0 . 8 5 1}$ & 0.055 & 0.317 & 0.094 \\
$\mathrm{Ca}^{2+}$ & 0.439 & -0.125 & -0.585 & -0.026 \\
$\mathrm{Mg}^{2+}$ & 0.364 & -0.560 & 0.043 & $\mathbf{0 . 5 4 3}$ \\
$\mathrm{Na}^{+}$ & $\mathbf{0 . 6 6 0}$ & $\mathbf{0 . 5 5 2}$ & -0.010 & 0.130 \\
$\mathrm{~K}^{+}$ & 0.469 & 0.030 & 0.404 & -0.634 \\
$\mathrm{HCO}_{3}^{-}$ & 0.224 & $\mathbf{0 . 5 5 5}$ & -0.449 & 0.339 \\
$\mathrm{Cl}^{-}$ & $\mathbf{0 . 7 6 8}$ & -0.267 & -0.023 & -0.113 \\
$\mathrm{SO}_{4}^{2-}$ & -0.195 & -0.150 & $\mathbf{0 . 6 5 4}$ & 0.430 \\
$\mathrm{NO}_{3}^{-}$ & $\mathbf{0 . 8 1 3}$ & 0.043 & 0.166 & -0.113 \\
$\mathrm{~F}^{-}$ & -0.033 & $\mathbf{0 . 7 3 2}$ & 0.176 & 0.107 \\
Eigenvalue & 3.14 & 1.75 & 1.40 & 1.11 \\
$\%$ Total variance & 28.50 & 15.94 & 12.69 & 10.07 \\
Cumulative \% & 28.50 & 44.44 & 57.13 & 67.20 \\
\hline
\end{tabular}




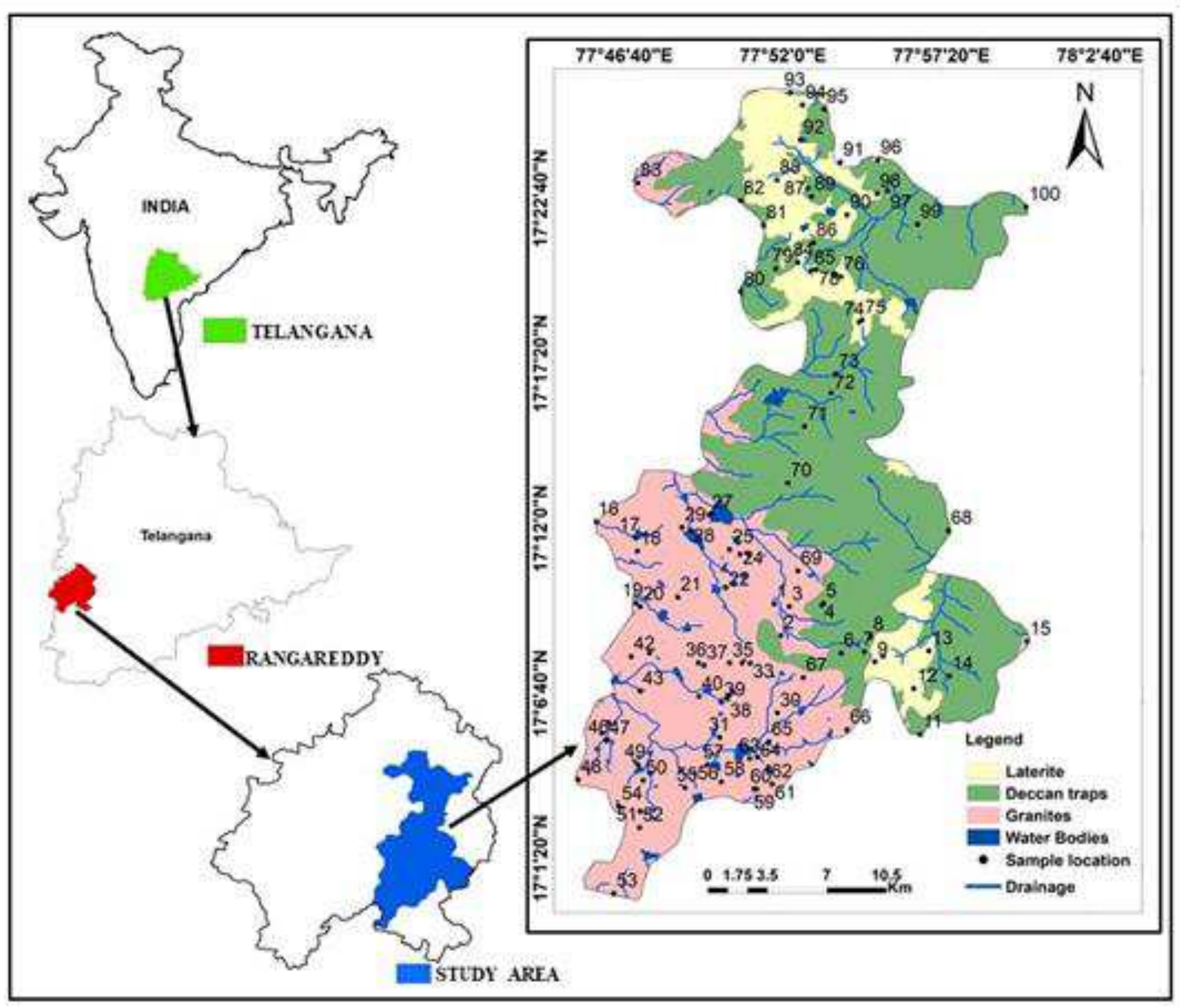

Fig. 1. Map showing the location of the rural region of the present study 
(a)

(b)
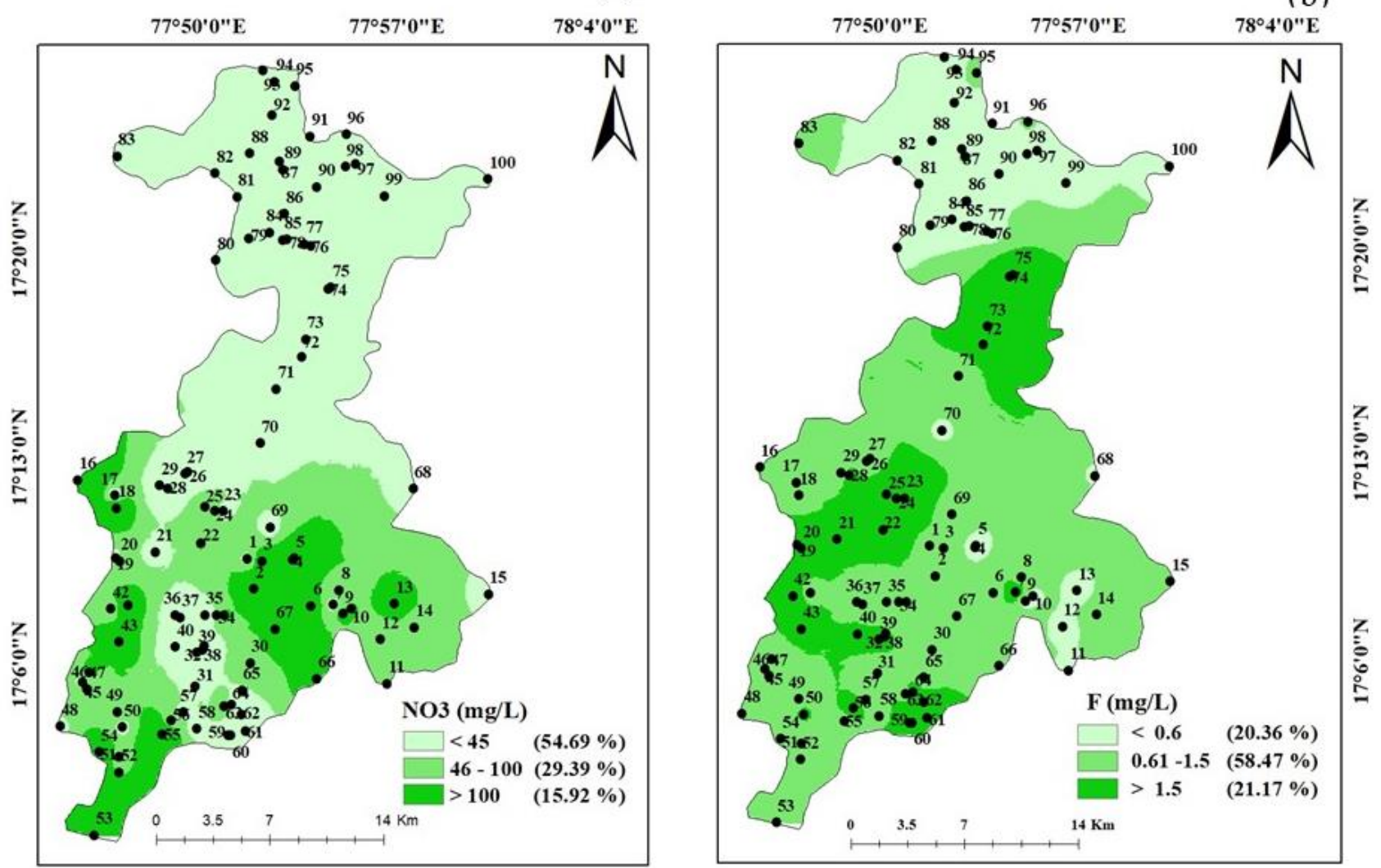

Fig. 2. Map showing the spatial distribution of (a) $\mathrm{NO}_{3}^{-}$and (b) $\mathrm{F}^{-}$ions 
(a)

(b)
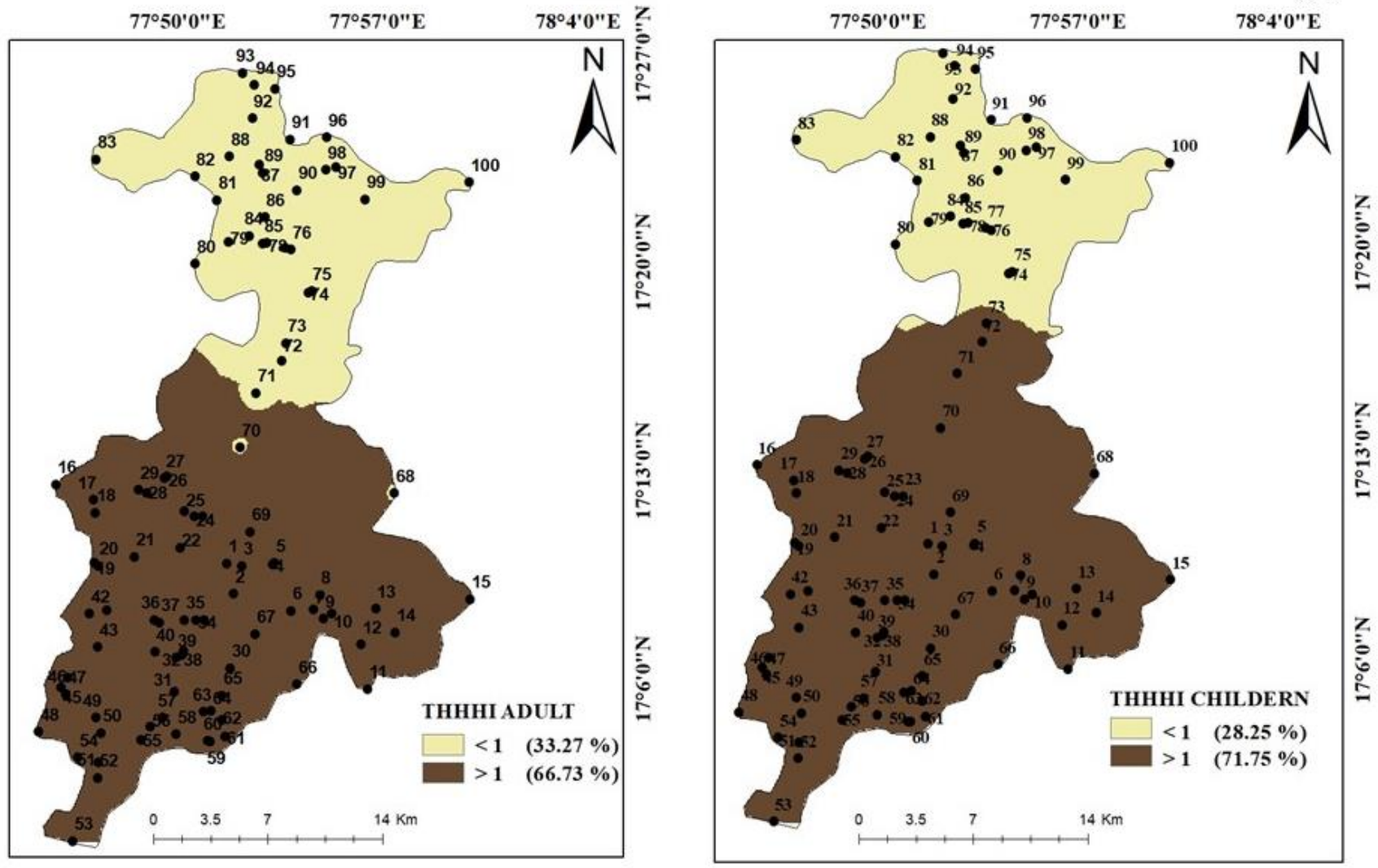

Fig. 3. Map showing the spatial distribution of total human health hazard index (THHHI) with respect to (a) adults and (b) children 